\title{
Kunhalmok élőhely-rekonstrukciójának eredményei a Hortobágyi Nemzeti Parkban
}

\author{
Radócz Szilvia \\ Debreceni Egyetem, Ökológiai Tanszék \\ 4032 Debrecen, Egyetem tér 1. \\ e-mail: radoczszilvia88@gmail.com
}

\begin{abstract}
Összefoglalás: Alföldi körülmények között a kunhalmok kiemelkedő kulturális és tájképi értékeik mellett számos ritka növény- és állatfajnak nyújtanak menedéket. Emiatt kezelésük és rekonstrukciójuk a természetvédelem fontos feladata. Munkánk során négy kunhalmon végeztünk élőhelyrekonstrukciót és növények telepítését. A közönséges ördögcérna (Lycium barbarum) mennyisége az alkalmazott kezelés (kaszálás és vegyszeres kezelés) hatására jelentős mértékben visszaszorult, ezáltal a vetett és ültetett célfajok nagy számban meg tudtak telepedni. A magvetés csak a megfelelő talajelőkészítést követően bizonyult sikeresnek. A palántázás és a növény áttelepítés a rossz csíraképességü növényfajok esetében jó módszernek bizonyult. Az állapot fenntartása érdekében folyamatos utógondozás szükséges, mely során a kaszálást idővel az alacsony intenzitású legeltetés is felválthatja.
\end{abstract}

Kulcsszavak: kulturális ökoszisztéma szolgáltatások, veszélyeztetett fajok, gyeprekonstrukció, egyedi tájérték, növény-áttelepítés

\section{Bevezetés}

A gyepi élőhelyek kiemelkedően nagy biológiai sokféleséggel rendelkeznek, és természeti örökségünk fontos részét képezik (Valkó et al. 2016a). Európában az elmúlt évszázadok intenzív tájhasználata miatt állományaik kiterjedése jelentősen csökkent (Lindborg et al. 2015, Hüse et al. 2016). Az élőhelyvesztés, fragmentáció, izoláció, valamint a hagyományos gazdálkodási módok megszünése a természetes élőhelyek degradációjához és a biológiai sokféleség csökkenéséhez vezetett (Valkó et al. 2012, Tälle et al. 2016). A hagyományos gazdálkodási módok és az egyedi tájértékek megőrzése ezért a természetes élőhelyek és a hozzájuk kötődő kulturális ökoszisztéma szolgáltatások fenntartásához egyaránt hozzájárul (Jones et al. 2016). A történelmi tájelemek és a gyepi biodiverzitás megörzésének összekapcsolása növelheti a társadalom tudatosságát is (Plieninger et al. 2015). 
Az őskori temetkezési halmok, amelyeket „kurgánoknak”, illetve „kunhalmoknak" neveznek, ideális célterületei lehetnek a kis léptékü természetvédelmi projekteknek. Méretük néhány száz négyzetmétertől egy hektárig terjed, magasságuk általában 1 és 15 méter között van (Deák et al. 2016a). A kunhalmok becsült száma 400-600.000 a sztyeppi régióban (Deák et al. 2016a), a sztyeppi életközösségek tipikus élőhelyei (Deák et al. 2015, 2018, Novák et al. 2009). A halmok különleges alakja és meredek lejtői gyakran megakadályozták a beszántásukat; és így a löszgyepi vegetáció képes volt fennmaradni a kunhalmokon (Deák et al. 2016b, Dembicz et al. 2016). Azonban a halmok növényzetét egész Eurázsiában veszélyezteti az emberi zavarásból, fásszárúak terjedéséből és nem megfelelő kezelésből adódó degradáció (Deák et al. 2016a,b, Tóth \& Tóth 2011). A halmok fontosságát az Európai Táj Egyezmény is elismerte, ahol a tipikus magyarországi tájelemek között szerepelnek (Jones 2007, Jones et al. 2016). A kunhalmok eredeti vegetációjának helyreállításához sok esetben aktív természetvédelmi beavatkozások szükségesek. Az eredeti élőhelyekre jellemző növényközösségek ugyanis a propagulumok hiánya miatt sokszor nem képesek spontán módon visszatelepedni a degradált élőhelyekre (Baur 2014, Valkó et al. 2016b).

A vizsgálat célja négy halom eredeti növényzetének helyreállítása és a gyepekre jellemző növényfajok megtelepítése volt. Az alábbi kérdésekre kerestük a választ: Mely fajok tudnak a legeredményesebben megtelepedni? Melyik módszer a leghatékonyabb a célfajok megtelepedéséhez és hogyan tudjuk fokozni a kezelések hatékonyságát?

\section{Anyag és módszer}

\section{Mintaterületek}

Mintaterületeink Egyek-Pusztakócson, a Hortobágyi Nemzeti Park területén találhatóak ( $\left.\mathrm{N} 47,58^{\circ}, \mathrm{E} 20,92^{\circ}\right)$. A jó minőségü termékeny csernozjom talajok miatt, a térségben a löszgyepek jelentős részét szántóföldekké alakították át, így a löszgyepek föként csak a szántóföldi gazdálkodásra alkalmatlan területeken maradtak fenn, például a kunhalmokon (Deák et al. 2014). Munkánk során négy kunhalmon végeztünk természetvédelmi gyeprekonstrukciós beavatkozásokat 2011 és 2014 között. 2011-ben a kunhalmok növényzete degradált állapotot mutatott, azokat fajszegény löszgyep borította. A gyepben megtalálhatóak voltak a löszgyepi vázfajok, mint például a Festuca rupicola, Poa angustifolia és Bromus inermis. Azonban számos jó kompetítor képességgel rendelkező, természetvédelmi szempontból nem kívánatos gyomfaj is jelen volt a vegetációban (Bromus sterilis, Carduus acanthoides, Cirsium arvense, Lycium barbarum) és a löszgyepekre jellemzö 
kísérőfajok hiányoztak. Célunk a halmokon található gyepek természetközeli állapotának helyreállítása volt: a Lycium barbarum visszaszorítását, magvetéses gyepesítést, növényegyedek kiültetését és áttelepítését tüztük ki célul.

\section{Természetvédelmi beavatkozások}

Két kunhalmot (Filagória: N $47.573271^{\circ}$ E $20.942839^{\circ}$, Meggyes: N $47.585222^{\circ}$ E 20.973992 ${ }^{\circ}$ 2011-2014-ig kora tavasszal, nyár végén és ősszel, évi háromszori kézi kaszálással kezeltünk, minden esetben a kaszálékot eltávolítottuk. A másik két kunhalmon (Nyíregyházi: N 47.570090 E 20.951617², Porosállás: $\mathrm{N} 47.550524^{\circ} \mathrm{E} 20.881466^{\circ}$ ) évi egyszeri nyár végi gépi kaszálás volt a kezelés módja. A Lycium barbarum-ot a többszöri kaszálással kezeltünk és célzott vegyszeres gyomirtást is végeztünk Medallon injektálással és ecseteléssel 2011 és 2012 őszén. A gyökereket kézi erővel is igyekeztünk eltávolítani, így a növény terjedését sikerült visszaszorítani a Filagória- és Meggyes-halom területén. A kiindulási évben ezen két halom jelentős része be volt nőve ördögcérnával.

A kunhalmokon a gyepi mátrixfajokat (Filipendula vulgaris, Salvia austriaca és a $S$. nemorosa), valamint további 12 kísérőfajt kézi magvetéssel (2013 szeptemberében), míg a ritkább kísérő fajokat palántázással (11 faj), illetve veszélyeztetett populációkból való áttelepítéssel (3 faj) 2014 szeptemberében telepítettük a halmokra (1. táblázat). A magkeverékhez szükséges magokat a régió löszgyepjeiből gyüjtöttük be kézi erővel, a kunhalmok 50 km-es körzetében a terület felelősével elöre egyeztetett időpontban és helyszínen. A magok esetében nem történt semmiféle mechanikai beavatkozás, begyüjtés után a lehető leghamarabbi időpontban megtisztítottuk, és száraz, hüvös helyen, szobahőmérsékleten tároltuk őket. A magok életképességét csíráztatással vizsgáltuk, fajonként 3 ismétlésben 100 magot csíráztattunk üvegházi körülmények között 2013 októberétől 2014 júniusáig. A magvetéses gyepesítéshez a talajelőkészítés során megfelelő aprómorzsás szerkezetủ magágyat készítettünk (kaszálás, rotációs kapa, gereblyézés). A löszgyepekre jellemző három kétszikủ mátrixfaj (500 g) és 12 kísérő kétszikü faj (20-20 g) magjait vetettük el (1. táblázat).

A következő év magvetéses gyepesítés felméréseinek eredményei alapján (2. táblázat) sok olyan kétszikü faj volt, mely nem telepedett meg, ezért 2014 szeptemberében a saját magunk által üvegházi körülmények között kinevelt 11 kétszikü faj palántáit ültettük ki (1. táblázat). A kiültetett palánták méretei fajonként eltérőek voltak, de a kiültetetésre került palánták mindegyike elérte azt a mérettartományt, mely a megmaradásukhoz szükséges (10-20 cm közötti méret volt a jellemző).

Három védett fajt (Amygdalus nana, Anchusa barrelieri és Phlomis tuberosa) telepítettünk át (1. táblázat) veszélyeztetett természetes populációkból, ahol az út 
1. táblázat: A négy kunhalomra betelepített fajok listája. (A) magvetéses gyepesítés magtömegei (g/halom), (B) Üvegházi körülmények között felnevelt, kiültetett palánták mennyiségei (tő/halom), (C) veszélyeztetett természetes populációkból áttelepített fajok mennyiségei (tő/halom) A mátrix fajokat csillaggal jelöltük.

\section{Filagória Meggyes Nyíregyházi Porosállás}

(A) Magvetés (g) (2013 ősz)

Carthamus lanatus

20

Centaurea pannonica

$20 \quad 20$

20

Centaurea sadleriana

20

20

Centaurea solstitialis

20

Dianthus pontederae

20

20

Filipendula vulgaris*

500

20

20

Galium verum

20

Hypericum perforatum

20

Knautia arvensis

20

Lotus corniculatus

500

500

500

Lycopsis arvensis

Phlomis tuberosa

Salvia austriaca*

Salvia nemorosa*

Silene vulgaris

(B) Kiültetés (tő) (2014 ősz)

Carthamus lanatus

Centaurea pannonica

Centaurea sadleriana

50

50

Dianthus pontederae

20

20

50

Filipendula vulgaris

20

20

30

50

Lotus corniculatus

Phlomis tuberosa

Rosa rubiginosa

49

Salvia austriaca

30

Salvia nemorosa

10

20

50

Silene vulgaris

36

20

(C) Áttelepítés (tő) (2014ősz)

Amygdalus nana

Anchusa barrelieri

32

10

Phlomis tuberosa 
2. táblázat: A betelepítés eredményessége. (A) magvetéses gyepesítés eredményei (tőszám összesen), (B) üvegházi körülmények között felnevelt, kiültetett palánták megmaradási arányai (tőszám összesen) (C) veszélyeztetett, természetes populációkból áttelepített egyedek megmaradási arányai (tőszám összesen). Csillaggal jelöltük a virágzó egyedekkel rendelkező populációkat.

\begin{tabular}{|c|c|c|c|c|}
\hline & Filagória & Meggyes & Nyíregyházi & Porosállás \\
\hline \multicolumn{5}{|l|}{ (A) Magvetés (tő) (2014) } \\
\hline Carthamus lanatus* & & 27 & & \\
\hline Centaurea pannonica & 0 & 0 & 0 & 0 \\
\hline Centaurea sadleriana & 0 & & 0 & \\
\hline Centaurea solstitialis* & 15 & 100 & & \\
\hline Dianthus pontederae & 0 & 0 & 0 & 0 \\
\hline Filipendula vulgaris & 0 & 0 & 0 & 0 \\
\hline Galium verum* & 24 & & & \\
\hline Hypericum perforatum* & 18 & & & \\
\hline Knautia arvensis* & 8 & & & \\
\hline Lotus corniculatus & & & & 0 \\
\hline Lycopsis arvensis* & & 27 & & \\
\hline Phlomis tuberosa & 0 & 0 & 0 & 0 \\
\hline Salvia austriaca* & 490 & 29 & 0 & 4 \\
\hline Salvia nemorosa* & 386 & 341 & 5 & 21 \\
\hline Silene vulgaris* & 5 & 0 & 0 & \\
\hline \multicolumn{5}{|l|}{ (B) Kiültetés (tő) (2015) } \\
\hline \multicolumn{5}{|l|}{ Carthamus lanatus } \\
\hline Centaurea pannonica* & 4 & 1 & & \\
\hline Centaurea sadleriana* & 4 & & 0 & \\
\hline \multicolumn{5}{|l|}{ Centaurea solstitalis } \\
\hline Dianthus pontederae & 0 & 0 & 0 & \\
\hline Filipendula vulgaris & 2 & 0 & 0 & \\
\hline \multicolumn{5}{|l|}{ Lotus corniculatus } \\
\hline Phlomis tuberosa & 10 & & & \\
\hline Rosa rubiginosa & 37 & & & \\
\hline Salvia austriaca* & & 6 & 1 & 3 \\
\hline Salvia nemorosa* & 30 & 9 & 2 & 18 \\
\hline Silene vulgaris * & 2 & 0 & & \\
\hline \multicolumn{5}{|l|}{ (C) Áttelepítés (tő) (2015) } \\
\hline Amygdalus nana & 13 & & & \\
\hline Anchusa barrelieri* & & & 18 & \\
\hline Phlomis tuberosa* & 10 & 3 & 40 & 15 \\
\hline
\end{tabular}


menti intenzív kaszálás, vegyszerezés és beszántás veszélyeztette az állományokat. Az áttelepítésénél igyekeztünk a lehető legnagyobb gyeptéglákat kiásni, hogy növeljük a megmaradás sikerességét. A macskahere és a törpemandula esetén körülbelül $50 \times 50 \mathrm{~cm}$-es gyeptéglákat, a kék atracél esetén $30 \times 30 \mathrm{~cm}$-es gyeptéglákat használtunk. A kiültetett palántákat, áttelepített egyedeket karókkal jelöltük, az utógondozásról (locsolás, mulcsozás) folyamatosan gondoskodtunk. Az OMSZ adatai alapján az adott időszakban a Tiszántúlon nagyobbrészt napos, száraz idő volt jellemző. A legalacsonyabb éjszakai hőmérséklet 12 és 17 fok között alakult. A legmagasabb nappali hőmérséklet a Tiszántúlon 29, 30 fok volt.

A vetett és kiültetett egyedek halmonkénti egyedszámát és virágzási sikerét 2015 június végén mértük fel.

\section{Eredmények}

A kiindulási állapotot tekintve a Meggyes-halom teljes területén a Lycium barbarum borítása $80 \%$ volt, melynek aránya a megfelelő kezelések hatására 2015-re 5\%-ra csökkent, míg a Filagória-halom esetében 60-80\%-os borítás $10 \%$-ra csökkent. A rendszeres utógondozás hatására a halmon korábban nagy borításban jelen levő gyomfajok visszaszorultak és egy természetközeli, fajgazdag, virággazdag gyep jött létre.

Megállapítottuk, hogy összesen 12 megtelepített faj virágzó hajtásokat is hozott (2. táblázat). A virágzó fajok legnagyobb arányát a kézi kaszálással kezelt halmokon (Filagória és Meggyes) találtuk. A mátrixfajok közül a Salvia austriaca és S. nemorosa, a kísérö fajok közül a Centaurea solstitialis és a Lycopsis arvensis megtelepedése volt a legsikeresebb (2. táblázat).

A kiültetett palánták közül a Filagória-halmon telepedett meg a legtöbb növényegyed, különösen a Phlomis tuberosa és Rosa rubiginosa megtelepedése volt sikeres (2. táblázat). Az áttelepített fajok közül az Amygdalus nana egyedek mintegy 30\%-a maradt meg a Filagória-halmon. A Nyíregyházi-halomra telepített Anchusa barrelieri több mint fele telepedett meg. Az áttelepített Phlomis tuberosa egyedeknek a Nyíregyházi- és Porosállás-halmokon mintegy 75\%-a maradt meg (2. táblázat).

\section{Értékelés}

Eredményeink alapján elmondható, hogy a halmokon a Lycium barbarum jelentős visszaszorulása következtében a vetett és ültetett célfajok jelentős mennyiségben fennmaradtak, virágoztak és magokat érleltek. Kimutattuk, hogy mindhárom 
módszer (magvetés, átültetés és áttelepítés) alkalmas lehet a növényfajok megtelepítésére. Eredményeink alapján a módszer kiválasztásakor figyelembe kell venni számos körülményt, például a termőhelyi adottságokat, a kezelési módot, a fajok jellemzőit, a rendelkezésre álló munkaerőt és a pénzügyi korlátokat.

Megállapítottuk, hogy a vetés költséghatékony módszert jelentett a nagy magvú fajok megtelepítésére, míg az üvegházi körülmények között felnevelt palánták kiültetésével garantáltan nagyobb eredménnyel, hosszú távon tudtak megtelepedni a célfajok. Az összes gyüjtött faj magja az üvegházi körülmények között csírázott, de a kemény maghéjú fajok (Lotus corniculatus, Lycopsis arvensis, Phlomis tuberosa, Salvia austriaca) és a fészkesvirágzatúak (Carthamus lanatus, Centaurea pannonica és $C$. sadleriana) csírázási aránya mérsékelt volt. Egyrészt a keményhéjú fajok csírázásához sokszor szükséges a maghéj megsértése (Baskin \& Baskin 1998), másrészt a fészkesvirágzatú fajok magjainak csíraképességét sokszor csökkentik a magfogyasztó rovarok (Steffan-Dewenter et al. 2001). A magvetés csak talajbolygatást követöen sikeres (Klaus et al. 2017), ami felhívja a figyelmet a talaj-előkészítés fontosságára (Deák et al. 2013). Eredményeink alapján a palántázás és áttelepítés a rossz magprodukciójú, illetve rosszul csírázó növényfajoknál biztosabb eredményt ad a magvetésnél.

Megállapítottuk, hogy a magvetés a kézi kaszálással kezelt halmokon volt a legsikeresebb. A kézi kaszálás a növények csírázásához kedvezőbb mikro-élőhelyek kialakulását eredményezi (Valkó et al. 2011), összehasonlítva a gépi kasza által létrehozott homogén vegetációs struktúrával (Humbert et al. 2009). Az állapot fenntartása és további javulása érdekében szükséges a halmok további kezelése, minimum évente háromszori kaszálása és a telepített növényegyedek sorsának nyomon követése. Az első években figyelni kell arra, hogy a kiültetett növényegyedeket kikerülve kell a kaszálást végezni. A későbbiekben a kaszálást alacsony intenzitású legeltetés is felválthatja.

Köszönetnyilvánítás - Köszönet illeti Valkó Orsolyát, Deák Balázst, Tóthmérész Bélát, Miglécz Tamást, Kelemen Andrást, Tóth Katalint, Sonkoly Juditot, Kiss Rékát és Tóth Edinát a terepi és üvegházi munkában nyújtott sokrétủ segítségükért. Köszönöm Dr. Bartha Sándor és Dr. Tóth Csaba Albert a kézirat bírálata során adott hasznos tanácsait. A helyreállítási projektet a KEOP-3.1.2/2F/09-11-2011-0009 projekt finanszírozta. A tanulmányt és a szerzőt az OTKA PD 111807, NKFI KH 126476, OTKA PD 115627 és OTKA K 116639 projektek támogatták.

\section{Irodalomjegyzék}

Baskin, C.C. \& Baskin, J.M. (1998): Seeds: Ecology, Biogeography, and Evolution of Dormancy and Germination. - Elsevier, $1600 \mathrm{p}$. 
Baur, B. (2014): Dispersal-limited species: A challenge for ecological restoration. - Basic Appl. Ecol. 15: 559-564. doi: https://doi.org/10.1016/j.baae.2014.06.004.

Deák, B., Tölgyesi, Cs., Kelemen, A., Bátori, Z., Gallé, R., Bragina, T.M., Abil, Y.A. \& Valkó, O. (2017): Vegetation of steppic cultural heritage sites in Kazakhstan - Effects of micro-habitats and grazing intensity. - Plant Ecol. Divers. 10: 509-520. doi: https://doi.org/10.1080/17550874 .2018 .1430871

Deák, B., Tóthmérész, B., Valkó, O., Sudnik-Wójcikowska, B., Bragina, T., Moysiyenko, I., Apostolova, I., Bykov, N., Dembicz, I. \& Török, P. (2016a): Cultural monuments and nature conservation: The role of kurgans in maintaining steppe vegetation. - Biodivers. Conserv. 25: 2473-2490. doi: https://doi.org/10.1007/s10531-016-1081-2

Deák, B., Valkó, O., Török, P. \& Tóthmérész, B. (2016b): Factors threatening grassland specialist plants: A multi-proxy study on the vegetation of isolated grasslands. - Biol. Conserv. 204: 255-262. doi: https://doi.org/10.1016/j.biocon.2016.10.023

Deák, B., Török, P., Tóthmérész, B. \& Valkó, O. 2015: A hencidai Mondró-halom, a löszgyepvegetáció őrzője. - Kitaibelia 20: 143-149. doi: https://doi.org/10.17542/kit.20.143

Deák, B., Valkó, O., Alexander, C., Mücke, W., Kania, A., Tamás, J. \& Heilmeier, H. (2014): Finescale vertical position as an indicator of vegetation in alkali grasslands - Case study based on remotely sensed data. - Flora 209: 693-697. doi: https://doi.org/10.1016/j.flora.2014.09.005

Deák, B., Valkó, O. \& Kapocsi, I. (2013): Általános és alternatív természetvédelmi célú gyeptelepítési módszerek technológiai kivitelezése és költségei. In: Török, P. (szerk.) Gyeptelepítés elmélete és gyakorlata az ökológiai szemléletű gazdálkodásban. Budapest, Ökológiai Mezőgazdasági Kutatóintézet. pp. 77-82.

Dembicz, I., Moysiyenko, I., Shaposhnikova, A., Vynokurov, D., Kozub, L. \& Sudnik-Wójcikows$\mathrm{ka}, \mathrm{B}$. (2016): Influence of isolation and size of a habitat patch on plant species density on kurgans and within other refuges of Ukrainian steppe. - Biodivers. Conserv. 25: 2289-2307. doi: https://doi.org/10.1007/s10531-016-1077-y

Humbert, J-Y., Ghazoul, J. \& Walter, T. (2009): Meadow harvesting techniques and their impacts on field fauna. - Agric. Ecosys. Environ. 130: 1-8. doi: https://doi.org/10.1016/j.agee.2008.11.014

Hüse, B., Szabó, S., Deák, B. \& Tóthmérész, B. (2016): Mapping ecological network of green habitat patches and their role in maintaining urban biodiversity in and around Debrecen city (Eastern Hungary). - Land Use Policy 57: 574-581. doi: https://doi.org/10.1016/j.landusepol.2016.06.026

Lindborg, R., Plue, J., Andersson, K. \& Cousins, S.A.O. (2015): Function of small habitat elements for enhancing plant diversity in different agricultural landscapes. - Biol. Conserv. 169: 206-213. doi: https://doi.org/10.1016/j.biocon.2013.11.015

Jones, M. (2007): The European Landscape Convention and the question of public participation. Landscape Res. 32: 613-633. doi: https://doi.org/10.1080/01426390701552753

Jones, P. J., Andersen, E., Capitani, C., Carvalho, Ribeiro, S., Griffiths, G. H., Loupa-Ramos, I., Madeira, L., Mortimer, S. R., Paracchini, M. L., Pinto, Correia, T., Schmidt, A. M., Simoncini, R. \& Wascher, D. M. (2016): The EU societal awareness of landscape indicator: A review of its meaning, utility and performance across different scales. - Land Use Policy 53: 112-122. doi: https://doi.org/10.1016/j.landusepol.2015.01.038

Klaus, V., Schäfer, D., Kleinebecker, T, Fischer, M., Prati, D. \& Hölzel, N. (2017): Enriching plant diversity in grasslands by large-scale experimental sward disturbance and seed addition along gradients of land-use intensity. - J. Plant Ecol. 10: 581-591. doi: https://doi.org/10.1093/jpe/ $\underline{\mathrm{rtw} 062}$

Novák, T., Nyilas, I. \& Tóth, Cs. (2009): Tájökológiai vizsgálatok a Zsolcai-halmok löszgyepein. Tájökol. Lapok 7: 161-173. 
Plieninger, T., Hartel, T., Martín-López, B., Beaufoy, G., Bergmeier, E., Kirby, K., Montero, MJ., Moreno, G., Oteros-Rozas, E. \& Van Uytvanck, J. (2015): Wood-pastures of Europe: Geographic coverage, social-ecological values, conservation management, and policy implications. - Biol. Cons. 190: 70-79. doi: https://doi.org/10.1016/j.biocon.2015.05.014

Steffan-Dewenter, I., Münzenberg, U. \& Tscharntke, T. (2001): Pollination, seed set and seed predation on a landscape scale. - Proc. Royal. Soc. B. 268: 1685-1690. doi: https://doi.org/10.1098/ rspb.2001.1737

Tälle, M., Deák, B., Poschlod, P., Deák, B., Poschlod, P., Valkó, O., Westerberg, L. \& Milberg, P. (2016): Grazing vs. mowing: a meta-analysis of biodiversity benefits for grassland management. - Agric. Ecosys. Environ. 15: 200-212. doi: https://doi.org/10.1016/j.agee.2016.02.008

Tóth, Cs. \& Tóth, A. (2011): The complex condition assessment survey of kurgans in Hungary. In Petô, Á. \& Barczi, A. (szerk.) Kurgan studies: an environmental and archaeological multiproxy study of burial mounds in the Eurasian steppe zone. British Archaeological Reports International Series 2238. Oxford: Archaeopress, pp. 9-17.

Valkó, O., Zmihorski, M., Biurrun, I., Loos, J., Labadessa, R. \& Venn, S. (2016a): Ecology and conservation of steppes and semi-natural grasslands. - Hacquetia 15: 5-14. doi: https://doi. org/10.1515/hacq-2016-0021

Valkó, O., Deák, B., Török, P., Kelemen, A., Miglécz, T., Tóth, K. \& Tóthmérész, B. (2016b): Abandonment of croplands: problem or chance for grassland restoration? Case studies from Hungary. - Ecosys. Health Sustainability 2: e01208. doi: https://doi.org/10.1002/ehs2.1208

Valkó, O., Török, P., Matus, G. \& Tóthmérész, B. (2012): Is regular mowing the most appropriate and cost-effective management maintaining diversity and biomass of target forbs in mountain hay meadows? - Flora 207: 303-309. doi: https://doi.org/10.1016/j.flora.2012.02.003

Valkó, O., Török, P., Tóthmérész, B. \& Matus, G. (2011): Restoration potential in seed banks of acidic fen and dry-mesophilous meadows: Can restoration be based on local seed banks? Restor. Ecol. 19: 9-15. doi: https://doi.org/10.1111/j.1526-100X.2010.00679.x 


\title{
Grassland restoration and plant introduction on four kurgans in the Hortobágy National Park
}

\author{
Szilvia Radócz \\ University of Debrecen, Department of Ecology \\ H-4032 Egyetem tér 1, Debrecen, Hungary \\ e-mail: radoczszilvia88@gmail.com
}

Linking the conservation of cultural heritage and natural values provides a unique possibility for preserving traditional landscapes and receives an increased awareness from stakeholders and society. Ancient burial mounds are proper objects of such projects as they are iconic landscape elements of the Eurasian steppes and often act as refugia for grassland specialist species. Our aim was to reintroduce grassland plant species to burial mounds for representing them as cultural monuments with the associated biodiversity for the public. We tested the effectiveness of seed sowing, transplanting greenhouse-grown plants and individuals from threatened populations on burial mounds in Hortobágy National Park, Hungary. We answered the following questions: (1) Which method is the most effective for species introduction? (2) Which species can establish most successfully? (3) How does management affect the species establishment rates? We advise to use a combination of seed sowing and transplanting greenhouse-grown plants. We found that sowing was a cost-effective method for introducing large-seeded species, whilst introduction of greenhouse-grown transplants warranted higher establishment rates for a larger set of species. Transplanting adult individuals was more reliable regardless of management regimes, however this method is labour-intensive and expensive. Intensive management, like mowing with heavy machinery and intensive grazing should be avoided in the first few years after introduction. We highlighted that introducing characteristic grassland species on cultural monuments offers a great opportunity to link issues of landscape and biodiversity conservation. Our project demonstrated that by the revitalisation of cultural monuments cultural ecosystem services can also be restored.

Keywords: cultural ecosystem services, endangered species, grassland restoration, landscape conservation, landscape element, reintroduction 